\title{
The Marginal Cost of Public Funds in OECD COUNTRIES: HOURS OF WORK VERSUS LABOR FORCE PARTICIPATION
}

\author{
HENRIK JACOBSEN KLEVEN \\ Claus Thustrup KREINER
}

CESIFO WORKING PAPER No. 935

CATEGORY 1: Public FinANCE

APRIL 2003

\footnotetext{
An electronic version of the paper may be downloaded

- from the SSRN website:

www.SSRN.com

- from the CESifo website: www.CESifo.de
} 


\title{
The Marginal Cost of Public Funds in OECD COUNTRIES: HOURS OF WORK VERSUS LABOR FORCE PARTICIPATION
}

\begin{abstract}
A central finding of the modern labor market literature is that labor supply responses tend to be concentrated along the extensive margin (labor force participation) rather than the intensive margin (hours of work). Yet, the literature on the marginal cost of public funds (MCF) focuses solely on the intensive margin. In this paper we demonstrate that it is important to incorporate extensive labor supply responses into the analysis. Firstly, MCF becomes a function of average taxes, rather than just marginal taxes. Secondly, participation decisions and thus MCF depend on the magnitude of transfers for those out of work. Our calculations for 23 OECD countries reveal that the MCF becomes substantially higher once the participation e.ect is accounted for. This is especially the case for continental European countries where average taxes are high and benefit systems are generous.
\end{abstract}

JEL Code: H21, H41, J20.

\author{
Henrik Jacobsen Kleven \\ Institute of Economics \\ University of Copenhagen \\ Studiestraede 6 \\ DK-1455 Copenhagen $K$ \\ Denmark \\ henrik.kleven@econ.ku.dk
}

\author{
Claus Thustrup Kreiner \\ Institute of Economics \\ University of Copenhagen \\ Studiestraede 6 \\ DK-1455 Copenhagen $K$ \\ Denmark
}

We wish to thank Peter Birch Sørensen for helpful comments. The activities of EPRU (Economic Policy Research Unit) are supported by a grant from The Danish National Research Foundation. 


\section{Introduction}

The optimal size of government is a central concern to anyone interested in the economics of the public sector. The classic formulation of the problem goes back to Samuelson (1954) who analyzed the case where government is financed entirely by lump sum taxation. His analysis was later refined by Stiglitz and Dasgupta (1971) and Atkinson and Stern (1974) to account for the more realistic situation where revenue has to be raised by distortionary taxation. These papers demonstrated that a crucial factor for the optimal size of government is the marginal welfare cost of raising revenue by distortionary taxes, subsequently labelled the marginal cost of public funds (MCF) by Browning (1976).

The contribution by Browning and the literature that followed have discussed how to measure the MCF and tried to estimate its value for the United States. The literature has focused mostly on the effect of taxation on labor supply, e.g. Stuart (1984), Browning (1987), Fullerton (1991), Mayshar (1991), Ballard and Fullerton (1992), Snow and Warren (1996), and Dahlby (1998). Specifically, the model of labor supply employed in these papers deals exclusively with the effect of taxes on hours of work for those who are working. The decision of whether or not to enter the labor market is not included in the analysis. This is at variance with the modern labor market literature which emphasizes the importance of distinguishing between labor supply responses along the intensive margin (hours of work) and the extensive margin (labor force participation):

"A revision is in order for George Stigler's dictum that all elasticities are 1 in absolute value. A dictum closer to the truth would be that elasticities are closer to 0 than 1 for hours-of-work equations (or weeks-of-work equations) estimated for those who are working. A major lesson of the past 20 years is that the strongest empirical effects of wages and nonlabor income on labor supply are to be found at the extensive margin - at the margin of entry and exit - where the elasticities are definitely not zero." Heckman (1993, p. 118). 
The distinction between hours of work and participation, stressed so clearly in the above statement, seems to be important for the welfare cost of taxation. Firstly, participation decisions depend on the average - rather than the marginal - rate of taxation. This introduces a role for average taxes in the determination of $\mathrm{MCF}$, unlike the traditional measures emphasizing the effect of marginal taxes on working hours. Secondly, the choice to participate in the labor market is influenced by outside opportunities, implying that transfers for those out of work (like UI benefits, social assistance, housing benefits, food stamps, etc.) play a role for the magnitude of the MCF. The fact that entry-exit behavior constitutes most of the observed variation in labor supply serves to make these theoretical points all the more important.

Against this background, we generalize the MCF measure to account for both margins of labor supply response. We then calculate the revised MCF for 23 OECD countries. The revised MCF includes the standard term, operating through the intensive margin, and an additional term which works through the extensive margin. The new term depends on the level of average taxes and transfers as well as the elasticity of participation with respect to the after tax wage rate. The presence of extensive labor supply responses unambiguously increases the welfare cost of raising additional tax revenue.

To estimate MCF, we use OECD data on taxes and benefits for the average production worker in each country. The inclusion of benefits raises some conceptual issues. The replacement rates reported by OECD may be overestimated for our purpose because of eligibility rules (relating to wealth, spouse's income, etc.) and because of various forms of workfare requirements which reduce the utility of the benefit recipient. To avoid this potential bias, we present two estimates of the MCF: one where benefits are excluded altogether (a lower bound) and another one which is based on the lowest benefit measure reported by OECD, namely that of a long-term 
recipient.

A benchmark case emphasized in the literature, for example by Ballard and Fullerton (1992), is where the additional revenue is raised by a proportional tax and where the uncompensated hours-of-work elasticity is equal to zero. The 'standard' MCF measure is equal to one in this case. ${ }^{1}$ The revised MCF, on the other hand, is always greater than one resulting from the participation effect. For a macro participation elasticity equal to 0.2 - a conservative estimate presumably - the MCF for the various countries lies in the interval from 1.15 to 2.52 if government transfers are included, while the interval is 1.09 to 1.80 without transfers. At the low end of the scale, United States has a benefit-inclusive MCF equal to 1.15 while the benefitexclusive value is 1.13. Other countries with relatively low MCFs include Japan, Australia, Canada, and the United Kingdom. In the high end, we have continental European countries such as Germany, France, Netherlands, Belgium, and the Scandinavian countries. For example, the MCF for Germany is equal to 1.55 or 2.12 depending on whether benefits are included or not.

The paper also investigates the possibility of Laffer curve effects. By construction, the MCF tends to infinity as the economy approaches the maximum of the Laffer curve and becomes negative thereafter. Our sensitivity analysis for the participation elasticity implies that this could happen for some European countries, even for proportional tax changes where the standard MCF would be one. For a participation elasticity equal to 0.4, our analysis indicates that countries like Austria, Finland, and the Netherlands have benefit-inclusive MCFs in excess of 10, while Germany and Belgium are beyond the Laffer curve's maximum.

\footnotetext{
${ }^{1} \mathrm{~A}$ qualification is in order here. The standard MCF is equal to one in the Stiglitz-Dasgupta-Atkinson-Stern approach, where the additional revenue is allocated to a public good which has no repercussions on labor supply. In the Pigou-Harberger-Browning tradition, on the other hand, government spending is assumed to neutralize any income effects of the tax change, implying that the MCF is always greater than one. See Wildasin (1984) and Ballard and Fullerton (1992) for detailed discussions of this issue.
} 
The relation of our paper to the existing literature may be interpreted in two different ways. In a literal interpretation, the literature deals only with the intensive margin of labor supply response, while our paper incorporates the margin of entry and exit into the analysis. The presence of this additional margin of labor supply response unambiguously increases the MCF and, consequently, the welfare cost of providing public goods becomes higher than previously estimated. Alternatively, one could think of the previous analyses as aggregate frameworks where the participation effect - although not explicitly modelled - is embodied in a macro labor supply function. For the estimation of MCF in the traditional approach, one should then use the aggregate labor supply elasticity including both margins of labor supply response. In this interpretation, our contribution is to demonstrate that the previous studies make a measurement error because they use the wrong wedge, namely the marginal tax rate instead of the sum of the average tax rate and the replacement ratio. Indeed, the measurement error thus committed would be quite large for most realistic tax systems.

The paper is organized in the following way. Section 2 derives our revised measure of the marginal cost of public funds. Section 3 briefly reviews the empirical evidence on extensive and intensive labor supply responses. Section 4 describes the tax/benefit data, while Section 5 presents calculations of the MCF for 23 OECD countries. Section 6 concludes.

\section{A Revised Measure of the Marginal Cost of Public Funds}

A way to account for labor supply responses along the participation margin, employed in the empirical labor market literature, is to introduce fixed costs of working into the analysis. These are costs such as child care or commuting costs which must be paid for any amount of work. We assume that the economy consists of a continuum of individuals who differ with respect to 
their fixed costs of working. The fixed cost is denoted by $\omega$ and, since it is the only source of heterogeneity, it is also used as the index parameter. Let $c(\omega)$ denote the consumption of type $\omega$, and let $l(\omega)$ denote the hours of work. Individual utility is then given by

$$
u(\omega)=\left\{\begin{array}{lll}
v(c(\omega), 1-l(\omega))-\omega & \text { for } & l(\omega)>0 \\
v(c(\omega), 1) & \text { for } & l(\omega)=0 .
\end{array}\right.
$$

In the case of labor market participation, the worker incurs the fixed utility cost $\omega$ and has leisure time $1-l(\omega)$. If the worker chooses to stay out of the labor force, he saves the fixed cost and gains leisure time. The budget constraint may be written as

$$
c(\omega) \leq w l(\omega)-T(w l(\omega), z)+y,
$$

where $w$ denotes the before-tax wage rate and $y$ is non-labor income. The $T$-function is the net payment to the public sector, including both taxes and transfers, and $z$ is a parameter which captures policy reform. The tax/transfer system may be proportional, progressive, or regressive, and it may involve non-linearities. Attention is restricted, however, to the case of piecewise linearity such that marginal rates are locally constant.

The household maximizes (1) subject to (2). In the case of participation, i.e. $l(\omega)>0$, the optimum is characterized by

$$
(1-m(z)) w v_{1}\left(c_{p}, 1-l_{p}\right)=v_{2}\left(c_{p}, 1-l_{p}\right)
$$

where $c_{p}$ and $l_{p}$ denote consumption and hours of work for a participating worker, while $m(z) \equiv$ $\partial T\left(w l_{p}, z\right) / \partial\left(w l_{p}\right)$ is his marginal tax rate.

For the individual to enter the labor market in the first place, the utility from participation must be greater than or equal to the utility from non-participation. This implies the following upper bound on the fixed cost of working:

$$
\omega \leq v\left(c_{p}, 1-l_{p}\right)-v\left(c_{n}, 1\right) \equiv \tilde{\omega}
$$


where $c_{n}=y-T(0, z)$ is the consumption for non-participants. Individuals with a fixed cost below the threshold-value $\tilde{\omega}$ decide to work $l_{p}$ hours, while those with a fixed cost above the threshold choose to stay outside the labor force. Letting the fixed cost $\omega$ be distributed according to the density function $g(\omega)$, the fraction of individuals who choose to participate in the labor market is given by $\int_{0}^{\tilde{\omega}} g(\omega) d \omega=G(\tilde{\omega})$. The aggregate labor supply thus becomes

$$
L=\int_{0}^{\infty} l(\omega) g(\omega) d \omega=l_{p} G(\tilde{\omega})
$$

where we have normalized the total population to one. Aggregate labor supply is a product of hours of work for those who are working and the labor force participation rate. Hence, the elasticity of labor supply with respect to the wage rate may be written as a sum of the hours-of-work elasticity, $\eta$, and the participation elasticity, $\delta$, i.e.

$$
\frac{\partial L / L}{\partial w / w}=\frac{\partial l_{p} / l_{p}}{\partial w / w}+\frac{\partial G / G}{\partial w / w}=\eta+\delta
$$

Note that $\eta$ is the uncompensated hours-of-work elasticity. From the Slutsky-equation, it may be decomposed into a compensated elasticity, $\eta^{c}$, and an income effect, $\theta$, that is

$$
\eta=\eta^{c}-\theta \gtrless 0,
$$

where $\theta \equiv-(1-m(z)) w \frac{d l_{p}}{d y}$ is positive if leisure is a normal good. Using (2) through (4), the participation elasticity is equal to

$$
\delta=\frac{g(\tilde{\omega}) w}{G(\tilde{\omega})} \frac{\partial \tilde{\omega}}{\partial w}=\frac{g(\tilde{\omega}) w}{G(\tilde{\omega})}[1-m(z)] l_{p} v_{1}>0
$$

where we have suppressed the arguments in the marginal utility of income, $v_{1}$. It is seen from the above expression that the participation elasticity is strictly positive, in contrast to the hours-of-work elasticity which has an indeterminate sign reflecting that the individual labor supply curve may be backward-bending. 
For the purpose of measuring the efficiency effects of raising revenue, we derive aggregate utilitarian welfare by integrating the utility function (1) over households, i.e.

$$
U=\int_{0}^{\infty} u(\omega) g(\omega) d \omega=\int_{0}^{\tilde{\omega}}\left[v\left(c_{p}, 1-l_{p}\right)-\omega\right] g(\omega) d \omega+\int_{\tilde{\omega}}^{\infty} v\left(c_{n}, 1\right) g(\omega) d \omega .
$$

Now, consider a policy reform, i.e. a marginal change in $z$, which raises additional revenue from the labor income tax without affecting the tax/transfer payments for those outside the labor force. The welfare effect of such a reform is given by

$$
\frac{d U}{d z}=\int_{0}^{\tilde{\omega}}\left[v_{1} \frac{d c_{p}}{d z}-v_{2} \frac{d l_{p}}{d z}\right] g(\omega) d \omega+\left[v\left(c_{p}, 1-l_{p}\right)-\tilde{\omega}-v\left(c_{n}, 1\right)\right] g(\tilde{\omega}) \frac{d \tilde{\omega}}{d z}
$$

where we have used that $d c_{n} / d z=-\partial T(0, z) / \partial z=0$. The first term measures the welfare effect of increased taxation for those staying in the labor market, while the second term captures the effect of people leaving the labor force. For the marginal worker, the utility of participation equals that of non-participation, cf. eq. (4), and therefore the second term vanishes. Moreover, using eqs (2), (3), and (5), we may rewrite the first term so as to get

$$
-\frac{d U / d z}{v_{1}}=\frac{\partial a}{\partial z} w L
$$

where $a\left(w l_{p}, z\right) \equiv T\left(w l_{p}, z\right) /\left(w l_{p}\right)$ is the average tax rate, and where $\frac{\partial a}{\partial z} \equiv \frac{\partial T}{\partial z} /\left(w l_{p}\right)$ is the change in the average tax rate following the reform. ${ }^{2}$ We are interested in the marginal cost of public funds, i.e., the welfare cost in (10) per additional dollar of tax revenue. In algebra,

$$
M C F=-\frac{d U / d z}{v_{1} \cdot d R / d z}
$$

where $R$ denotes aggregate tax revenue, which is given by

$$
R=\int_{0}^{\tilde{\omega}} T\left(w l_{p}, z\right) g(\omega) d \omega+\int_{\tilde{\omega}}^{\infty} T(0, z) g(\omega) d \omega .
$$

\footnotetext{
${ }^{2}$ In calculations of the marginal welfare effect, the choice of welfare measure does not matter. Thus, the welfare effect in equation (10) is consistent with all the common measures, for example the equivalent variation, the compensating variation, and the compensating surplus. See Fullerton (1991) for a discussion of these issues.
} 
The change in aggregate revenue following a reform equals

$$
\frac{d R}{d z}=\int_{0}^{\tilde{\omega}}\left[\frac{\partial a}{\partial z} w l_{p}+m w \frac{d l_{p}}{d z}\right] g(\omega) d \omega+(a+b) w l_{p} g(\tilde{\omega}) \frac{d \tilde{\omega}}{d z}
$$

where $b \equiv-T(0, z) /\left(w l_{p}\right)$ is the amount of transfers to those outside the labor force in proportion to gross wages (the replacement ratio). The direct effect of raising the average tax burden on labor income is of course to collect more revenue from workers, reflected by the first term in the square brackets. However, there are feedback effects from both margins of labor supply. The second term in the square brackets reflects that those staying in the labor market re-optimize their hours of work due to the reform. Moreover, some people choose to quit their jobs because of the higher average tax rate, as indicated by the last term. This reduces tax revenue and implies also higher aggregate transfer payments. Using eqs (2) through (8), the expression in (13) may be rewritten to (see the Appendix):

$$
\frac{d R}{d z}=\left[\frac{\partial a}{\partial z}-\frac{m}{1-m}\left(\frac{\partial m}{\partial z} \eta^{c}-\frac{\partial a}{\partial z} \theta\right)-\frac{a+b}{1-m} \frac{\partial a}{\partial z} \delta\right] w L
$$

Now, by inserting this expression and eq. (10) in eq. (11), we arrive at our measure for the $\mathrm{MCF}$

$$
M C F=\frac{1}{1-\frac{m}{1-m}\left(\Phi \eta^{c}-\theta\right)-\frac{a+b}{1-m} \delta}
$$

where $\Phi \equiv \frac{\partial m / \partial z}{\partial a / \partial z}$ measures the progressivity of the tax change. Notice that $\Phi$ reflects the ex ante policy change, i.e., the feed-back from behavioral changes to tax rates is not included in this parameter. The implication of accounting for participation responses is reflected by the last term in the denominator, while the remaining part of the expression is the 'standard' effect operating through the intensive margin. As demonstrated by several other studies, the hours-of-work effect depends on the marginal tax rate, the progressivity of the reform, as well 
as substitution and income effects on individual labor supply. The size of the participation effect, on the other hand, is influenced by the average tax rate, the replacement ratio, and the participation elasticity. The presence of this new term unambiguously increases the magnitude of MCF. ${ }^{3}$

An obvious question to ask is whether the incorporation of extensive labor supply responses is really trivial in the sense that it boils down to a reinterpretation of the elasticities in the standard framework. The expression in (15) demonstrates clearly that this is not the case. Firstly, the standard term is divided into an income effect and a substitution effect, weighted by the reform parameter, and there is no obvious way to assign the participation effect to one or the other. Secondly, there is a difference in the relevant wedge as the participation term depends on the average tax rate and the replacement ratio, rather than just the marginal tax rate.

A natural benchmark, emphasized by e.g. Ballard and Fullerton (1992), is where the additional revenue is raised through a proportional tax change $(\Phi=1)$ and where the uncompensated hours-of-work elasticity is zero $(\eta=0)$. In this case the standard MCF is exactly equal to one. The revised $\mathrm{MCF}$, on the other hand, becomes equal to

$$
\left.M C F\right|_{\substack{\Phi=1 \\ \eta=0}}=\frac{1}{1-\frac{a+b}{1-m} \delta}>1
$$

which is always greater than one. In fact, as we shall see in Section 5 , it is substantially greater

\footnotetext{
${ }^{3}$ In comparing our MCF measure with previous studies, we run into the complication that quite a few different measures have been proposed. Indeed, the literature has devoted considerable effort to comparing and reconciling various MCF measures, see for example Snow and Warren (1996), and Dahlby (1998). One matter creating disparities is that some studies assume decreasing returns to scale implying that before-tax wages become endogenous (e.g. Mayshar, 1991). Moreover, some papers define the $\Phi$-parameter to reflect the ex post rather than the ex ante change in tax rates, as pointed out by Dahlby (1998). Correcting for these deviations, the relationship between eq. (15) and some of the existing measures is as follows. For $\delta=0$, our result corresponds to that of Mayshar (1991, eq. 3) and Dahlby (1998, eq. 11, single-person version). For $\delta=0$ and $\theta=0$, we get Browning (1987, eq. 11). Finally, for $\delta=0$ and $\Phi=1$, our formula is equivalent to those of Wildasin (1984, eq. 16), Usher (1984, p. 409), and Mayshar (1991, eq. 1).
} 
than one for most OECD countries, assuming an empirically plausible participation elasticity.

Another interesting benchmark case is where the reform changes only average tax rates $(\Phi=0)$. Such a tax increase has a positive income effect on the number of working hours, provided that leisure is a normal good, and consequently the standard MCF is below one. In our analysis there is an additional effect since higher average taxes make it less attractive to participate in the labor market. Once this effect is accounted for, the MCF becomes

$$
\left.M C F\right|_{\Phi=0}=\frac{1}{1+\frac{m}{1-m} \theta-\frac{a+b}{1-m} \delta} \gtrless 1,
$$

which may be greater than one.

\section{Evidence on Intensive and Extensive Labor Supply Responses}

A central finding of the modern labor market literature, surveyed by Heckman (1993), Blundell and MaCurdy (1999), and Browning et al. (1999), is that most of the variation in labor supply occurs along the extensive - rather than the intensive - margin. Thus, hours-of-work responses are close to zero for most groups in the labor market. A benchmark scenario often considered in the MCF literature is where the compensated hours-of-work elasticity is 0.2 while the uncompensated elasticity is 0 (e.g. Stuart, 1984; Mayshar, 1991; Ballard and Fullerton, 1992). We focus on the same benchmark case, in order to facilitate comparability, but consider also other values.

Estimated participation responses are typically much larger, particularly for certain subgroups of the population. This is confirmed by a number of studies of the Negative Income Tax experiments in the United States, surveyed by e.g. Robins (1985). While participation responses tend to be fairly small for prime age males, the elasticities for married women, single female heads, and young people are typically in excess of 0.5 and sometimes close to unity. 
For example, in Ashenfelter's (1978) study of the experiments in Iowa and North Carolina, the elasticities for married males and females are 0.2 and 0.9 , respectively.

More recently, studies of the Tax Reform Act of 1986 find that the expansion of the Earned Income Tax Credit (EITC) has had large effects on the labor force participation of single women, especially for those with low education (Eissa and Liebman, 1996; Meyer and Rosenbaum, 2001). Even for women at the high end of the earnings distribution, Eissa (1995) finds that the participation elasticity is as high as 0.4 .

Non-experimental evidence for both the United States and Europe offers a similar picture (Mroz, 1987; Triest, 1990; Van Soest, 1995; Van Soest et al., 2002). Triest (1990) estimates that the participation elasticity for married women in the United States lies in the interval from 0.6 to 1.1. For the Netherlands, Van Soest (1995) finds that the labor supply elasticity for males lies in the interval from 0.1 to 0.2 , whereas the elasticity for females lies in the range from 0.5 to 1.0. Although these elasticities include the effect on both participation and hours, Van Soest's calculations reveal that, for both spouses, the principal effect comes through the participation response. A more recent study by Van Soest et al. (2002) suggests that the participation elasticity for married women lies in the range from 0.5 (for those with high education) to 0.8 (for those with low education).

Applying these empirical studies to our analysis is not a straightforward exercise as they all focus on various subgroups of the population while our MCF measure is based on a macro elasticity. To summarize the literature, the participation elasticity for prime age males tends to be small (perhaps around 0.1), while for females, low-income earners, and young people the estimates tend to be concentrated in the interval from $\frac{1}{2}$ to 1 . Against this background, a realistic value of the participation elasticity for the representative individual seems to be in the 
neighborhood of 0.2 or 0.3 .

Another line of empirical work has dealt with the effects of unemployment insurance and other out-of-work benefits on the incidence and duration of unemployment. A recent paper by Kruger and Meyer (2002) surveys the evidence from the US and a number of other OECD countries. They conclude that the estimated elasticities of lost work time with respect to unemployment insurance tend to be around one. To become compatible with our participation elasticity, this number have to be multiplied by the unemployment rate and divided by the net replacement rate. For realistic magnitudes of the unemployment rate ( 5 to 10 percent) and the net replacement rate (cf. the next section), the participation elasticity is 0.2 or more for the OECD countries which we consider.

Based on the evidence reviewed in this section, our MCF calculations use a macro elasticity of labor market participation equal to 0.2. As this may be a bit conservative, we also consider the implications of larger elasticities.

\section{Taxes and Benefits in OECD Countries}

OECD's detailed studies of tax and benefit systems across member countries provide an ideal basis for our comparative study of the marginal cost of public funds. Table I displays our calculations, based on OECD data for the year 1999, of the tax/benefit position of the average production worker in 23 countries. The table considers a person who is single and without children. The marginal and average tax rates which are used for the MCF calculations should reflect the combined effect of all taxes in reducing the net consumer wage below the marginal product of labor. Accordingly, the tax rates in columns two and three include personal income taxes, employees' and employer's compulsory social security contributions, together with any 
Table I. Tax and benefit rates for the average production worker in different OECD countries, year 1999

\begin{tabular}{|c|c|c|c|c|c|c|c|c|}
\hline \multirow[b]{2}{*}{ Country } & \multicolumn{4}{|c|}{ Tax and benefit rates } & \multicolumn{4}{|c|}{ Consumption-adjusted rates } \\
\hline & Marginal & Average & Benefits & Consumption & Marginal & Average & Benefits & Avg.+Benefits \\
\hline Australia & 44.5 & 25.9 & 24.5 & 10.8 & 49.9 & 33.1 & 22.1 & 55.2 \\
\hline Austria & 56.2 & 45.9 & 39.2 & 16.6 & 62.4 & 53.6 & 33.6 & 87.2 \\
\hline Belgium & 67.3 & 56.9 & 26.1 & 15.7 & 71.7 & 62.7 & 22.6 & 85.3 \\
\hline Canada & 47.3 & 31.1 & 17.6 & 11.7 & 52.8 & 38.3 & 15.8 & 54.1 \\
\hline Denmark & 51.1 & 44.5 & 33.5 & 21.3 & 59.7 & 54.2 & 27.6 & 81.8 \\
\hline Finland & 59.2 & 47.4 & 35.1 & 18.7 & 65.6 & 55.7 & 29.6 & 85.3 \\
\hline France & 53.2 & 48.1 & 21.7 & 15.4 & 59.4 & 55.0 & 18.8 & 73.8 \\
\hline Germany & 63.3 & 51.9 & 31.4 & 13.6 & 67.7 & 57.6 & 27.6 & 85.3 \\
\hline Greece & 44.1 & 35.7 & 6.6 & 15.5 & 51.6 & 44.3 & 5.7 & 50.0 \\
\hline Iceland & 39.0 & 24.2 & 39.7 & 18.4 & 48.5 & 36.0 & 33.5 & 69.5 \\
\hline Ireland & 57.6 & 32.4 & 23.5 & 19.6 & 64.5 & 43.5 & 19.6 & 63.1 \\
\hline Italy & 55.3 & 47.2 & 0.0 & 14.4 & 60.9 & 53.8 & 0.0 & 53.8 \\
\hline Japan & 28.9 & 24.0 & 27.7 & 6.3 & 33.1 & 28.5 & 26.0 & 54.5 \\
\hline Luxembourg & 49.2 & 34.6 & 37.1 & 18.0 & 56.9 & 44.6 & 31.5 & 76.0 \\
\hline Netherlands & 58.2 & 44.3 & 38.8 & 16.0 & 64.0 & 52.0 & 33.4 & 85.4 \\
\hline New Zealand & 21.0 & 19.4 & 31.4 & 16.1 & 31.9 & 30.6 & 27.1 & 57.6 \\
\hline Norway & 43.0 & 37.3 & 30.4 & 21.9 & 53.2 & 48.5 & 24.9 & 73.5 \\
\hline Portugal & 40.2 & 33.4 & 40.4 & 17.0 & 48.9 & 43.1 & 34.5 & 77.6 \\
\hline Spain & 45.6 & 37.5 & 18.8 & 12.6 & 51.7 & 44.5 & 16.7 & 61.2 \\
\hline Sweden & 52.4 & 50.5 & 35.6 & 14.8 & 58.5 & 56.9 & 31.0 & 87.9 \\
\hline Switzerland & 38.2 & 29.8 & 42.3 & 8.0 & 42.8 & 35.0 & 39.1 & 74.2 \\
\hline United Kingdom & 40.3 & 30.8 & 34.8 & 14.8 & 48.0 & 39.7 & 30.3 & 70.0 \\
\hline United States & 34.9 & 31.1 & 5.2 & 5.8 & 38.5 & 34.9 & 4.9 & 39.8 \\
\hline
\end{tabular}

Source: $\operatorname{OECD}(2000,2001 \mathrm{a}, \mathrm{b})$ and authors' own calculations.

Note: We consider the tax/benefit position of a single person with no children. The marginal and average tax rates in columns two and three include personal income taxes, employees' plus employer's compulsory social security contributions, and payroll taxes. The benefit level in column four is measured relative to the gross wage and includes those transfers obtainable by a longterm benefit recipient. A long-term benefit recipient is defined as a person who has been out of employment for 60 months and who is not disqualified to obtain transfers due to any means tests. The consumption tax ratios are calculated as total consumption taxes in proportion to aggregate consumption (we have used the most recent estimates which are from 1996). Consumptionadjusted tax rates are given by the formula $(T R+C T R) /(1+C T R)$, where $T R$ is the tax rate exclusive of consumption taxes and $C T R$ is the consumption tax ratio. Finally, the consumptionadjusted benefit rate is found by dividing the benefit rate by $1+C T R$. 
payroll taxes. The tax rates account for the impact of various tax reliefs. This includes standard reliefs, which are granted irrespective of actual expenses incurred by the taxpayer, as well as certain reliefs for work-related expenses. Reliefs relating to for example interest on qualifying loans, medical expenses, and charitable donations are not included. This seems defensible in the present context as these reliefs are not related to the entry-exit decision per se. ${ }^{4}$

The tax rates should also account for the fact that commodity taxation reduces the real consumer wage, thereby hampering the incentive to supply labor. Consumption tax ratios are reported in column four and incorporated in the measure for average and marginal taxes in columns five and six. These are the rates which are used for the MCF calculations. There is substantial variation between countries, with marginal tax rates lying in the interval from 31.9 to 71.7 percent and average taxes in the range from 28.5 to 62.7 percent. For the United States, for example, the marginal tax rate is 38.5 percent while the average tax rate is 34.9 percent. Most calculations of the MCF for the United States have been based on the tax estimates of Browning and Johnson (1984) for the year 1976, according to which the marginal tax rate is 42.7 percent and the average tax rate is 27.3 percent. The deviation of these tax rates from those used here is explained partly by the tax reforms of the past 25 years. Moreover, the Browning-Johnson estimates are really weighted averages of labor and capital taxes while our tax rates include only that which is related to labor income.

The MCF depends also on out-of-work net income, consisting of UI benefits, social assis-

\footnotetext{
${ }^{4}$ The estimated tax rates may not accurately capture the tax position of the representative individual. Alternatively, we could have used tax rates based on aggregate data, also known as implicit tax rates, for example calculated by Mendoza, Razin, and Tesar (1994), Mendoza, Milesi-Ferretti, and Asea (1997), and OECD (2001a). However, this method presents some problems in our context. Firstly, it does not separate average from marginal tax rates, which is an essential distinction for our purpose. Secondly, it is impossible to calculate the true tax rate on labor income through the use of aggregate data, except for a few countries. Instead, the calculations assume a similar tax treatment of labor and capital income (see OECD, 2001a, for a detailed discussion of this issue). Consequently, the implicit average tax ratios do not necessarily capture the wedge which is relevant for the decision to enter or exit the labor force.
} 
tance, housing benefits, food stamps, etc. However, the inclusion of such benefits raises some conceptual issues. The benefit levels reported by OECD may be overestimated for our purpose because of eligibility rules (relating to wealth, spouse's income, etc.) and because of workfare requirements which reduce the utility of the benefit recipient. In an attempt to handle this potential bias, we consider two cases: one where benefits are excluded altogether (a lower bound) and another one where we use the lowest benefit measure reported by OECD, namely that of a long-term recipient. Net benefit levels in proportion to gross wages are reported in columns 6 and 7, the latter column accounting for the effect of consumption taxes on the real value of out-of-work income. As with taxes, there is a great deal of variation. For example, in the United States the replacement ratio (corrected for consumption taxes) is 4.9 percent while for a number of European countries the ratio is above 30 percent. Finally, Table I reports the sum of the average tax rate for workers and the benefit ratio for non-workers, which is the wedge relevant for the decision to enter or exit the labor market.

\section{The Marginal Cost of Public Funds in OECD Countries}

We now have the information needed for the calculation of the MCF. In our benchmark scenario, we set the compensated hours-of-work elasticity, $\eta^{c}$, and the income effect, $\theta$, equal to 0.2, implying an uncompensated elasticity equal to 0 . Table II reports both the standard MCF measure (disregarding participation effects) and the revised MCF measure, based on a participation elasticity, $\delta$, equal to 0.2 . The results are reported for a proportional reform $(\Phi=1)$, a regressive reform $(\Phi=0)$, and a progressive reform $(\Phi=2)$.

The case where the additional revenue is raised by a proportional reform demonstrates very clearly the implications of accounting for extensive labor supply responses. The standard MCF 
Table II. The marginal cost of public funds in OECD countries for different reforms

\begin{tabular}{|c|c|c|c|c|c|c|c|c|c|}
\hline \multirow[b]{2}{*}{ Country } & \multicolumn{3}{|c|}{ Proportional reform $(\Phi=1)$} & \multicolumn{3}{|c|}{ Regressive reform $(\Phi=0)$} & \multicolumn{3}{|c|}{ Progressive reform $(\Phi=2)$} \\
\hline & Standard & Excl. benefits & Incl. benefits & Standard & Excl. benefits & Incl. benefits & Standard & Excl. benefits & Incl. benefits \\
\hline Australia & 1.00 & 1.15 & 1.28 & 0.83 & 0.94 & 1.02 & 1.25 & 1.50 & 1.72 \\
\hline Austria & 1.00 & 1.40 & 1.87 & 0.75 & 0.96 & 1.15 & 1.50 & 2.61 & 4.91 \\
\hline Belgium & 1.00 & 1.80 & 2.52 & 0.66 & 0.94 & 1.11 & 2.03 & 20.49 & -9.00 \\
\hline Canada & 1.00 & 1.19 & 1.30 & 0.82 & 0.94 & 1.01 & 1.29 & 1.63 & 1.83 \\
\hline Denmark & 1.00 & 1.37 & 1.68 & 0.77 & 0.97 & 1.12 & 1.42 & 2.30 & 3.36 \\
\hline Finland & 1.00 & 1.48 & 1.98 & 0.72 & 0.95 & 1.13 & 1.62 & 3.40 & 8.19 \\
\hline France & 1.00 & 1.37 & 1.57 & 0.77 & 0.98 & 1.08 & 1.41 & 2.30 & 2.92 \\
\hline Germany & 1.00 & 1.55 & 2.12 & 0.70 & 0.94 & 1.12 & 1.72 & 4.46 & 18.75 \\
\hline Greece & 1.00 & 1.22 & 1.26 & 0.82 & 0.97 & 0.99 & 1.27 & 1.66 & 1.72 \\
\hline Iceland & 1.00 & 1.16 & 1.37 & 0.84 & 0.95 & 1.09 & 1.23 & 1.49 & 1.85 \\
\hline Ireland & 1.00 & 1.32 & 1.55 & 0.73 & 0.89 & 0.99 & 1.57 & 2.56 & 3.57 \\
\hline Italy & 1.00 & 1.38 & 1.38 & 0.76 & 0.97 & 0.97 & 1.45 & 2.42 & 2.42 \\
\hline Japan & 1.00 & 1.09 & 1.19 & 0.91 & 0.99 & 1.07 & 1.11 & 1.23 & 1.36 \\
\hline Luxembourg & 1.00 & 1.26 & 1.55 & 0.79 & 0.95 & 1.10 & 1.36 & 1.89 & 2.61 \\
\hline Netherlands & 1.00 & 1.41 & 1.90 & 0.74 & 0.94 & 1.14 & 1.55 & 2.81 & 5.85 \\
\hline New Zealand & 1.00 & 1.10 & 1.20 & 0.91 & 1.00 & 1.08 & 1.10 & 1.22 & 1.36 \\
\hline Norway & 1.00 & 1.26 & 1.46 & 0.81 & 0.98 & 1.09 & 1.29 & 1.77 & 2.18 \\
\hline Portugal & 1.00 & 1.20 & 1.44 & 0.84 & 0.98 & 1.13 & 1.24 & 1.56 & 1.98 \\
\hline Spain & 1.00 & 1.23 & 1.34 & 0.82 & 0.97 & 1.04 & 1.27 & 1.66 & 1.88 \\
\hline Sweden & 1.00 & 1.38 & 1.74 & 0.78 & 0.99 & 1.16 & 1.39 & 2.26 & 3.41 \\
\hline Switzerland & 1.00 & 1.14 & 1.35 & 0.87 & 0.97 & 1.12 & 1.18 & 1.37 & 1.69 \\
\hline United Kingdom & 1.00 & 1.18 & 1.37 & 0.84 & 0.97 & 1.09 & 1.23 & 1.51 & 1.83 \\
\hline United States & 1.00 & 1.13 & 1.15 & 0.89 & 0.99 & 1.00 & 1.14 & 1.31 & 1.34 \\
\hline
\end{tabular}

\section{Source: $\operatorname{OECD}(2000,2001 \mathrm{a}, \mathrm{b})$ and authors' own calculations.}

Note: MCF is calculated from equation (16) using the tax and beneft rates reported in Table I. The compensated hours-of-work elasticity $\left(\eta^{c}\right)$ and the income effect $(\theta)$ are equal to 0.2 , implying an uncompensated elasticity $(\eta)$ equal to 0 . The standard MCF measure is calculated by setting the participation elasticity $(\delta)$ equal to 0 . The benefit-exclusive MCF and the benefit-inclusive MCF are derived for a participation elasticity equal to 0.2 . 
measure is exactly one. By contrast, the revised MCF lies in the interval from 1.15 to 2.52 if out-of-work benefits are accounted for, while the interval is 1.09 to 1.80 if benefits are excluded. At the low end of the scale, United States has a benefit-inclusive MCF equal to 1.15 while the benefit-exclusive value is 1.13 . Other countries with relatively low MCFs include Japan, Australia, Canada, and the United Kingdom. In the high end, we find continental European countries such as Germany, France, Netherlands, Belgium, and the Scandinavian countries. For example, the MCF for Germany is equal to 2.12 or 1.55 depending on whether benefits are included or not. In France the values of MCF are somewhat lower, namely 1.57 and 1.37.

Another interesting case is where the reform changes only average taxes, corresponding to a change in basic allowances or credits. As emphasized by Fullerton (1991), the standard MCF is always lower than one in this case due to the income effect on hours of work. Indeed, for $\Phi=0$ the table indicates that the standard MCF is below 0.9 for almost all countries. Accounting for participation effects, the benefit-exclusive MCF is close to one for a majority of countries and, once benefits are included, the MCF is greater than one for nearly all countries.

If revenue is raised through a progressive reform, the MCF becomes larger. In the table this is demonstrated for the case of $\Phi=2$ corresponding, for example, to an increase in the tax rate applying to the upper half of income. Even where benefits are not included, the MCF is greater than 2 for around half of the countries in the sample. By construction, the MCF tends to infinity as the economy approaches the maximum of the Laffer curve and becomes negative thereafter. Our estimates indicate that the reform is quite close to generating Laffer curve effects in some countries. For example, the benefit-exclusive MCF is higher than 20 for Belgium while the number is above 4 in Germany. If out-of-work net income is included, it turns out that Belgium is beyond the Laffer curve's maximum, while several other countries are 
close to the maximum as indicated by excessive MCF-values.

Table III gives an impression of the sensitivity of MCF to different assumptions about labor supply elasticities. In the table, we consider only proportional reforms. As the participation elasticity used above may be somewhat conservative, columns one through four consider the implications of higher elasticity estimates. If the participation elasticity is 0.3 , instead of 0.2 , the benefit-inclusive MCF in the United States increases from 1.15 to 1.24. For countries with higher average taxes and government transfers, the effect of raising the participation elasticity is more dramatic. The MCF is more than doubled for Germany while in Belgium the number is quadrupled. Increasing the participation elasticity to 0.4 , these two countries pass the maximum of the Laffer curve (negative MCF), while countries like Austria, Finland, and the Netherlands get MCFs in excess of 10 . Finally, the remaining columns consider alternative values of the uncompensated hours-of-work elasticity ( $\eta$ equal to 0.1 and -0.1). As for the participation elasticity, the sensitivity of MCF with respect to the hours-of-work elasticity is largest for those countries having relatively high taxes. In contrast to the participation elasticity, however, it is the marginal - rather than the average - tax rate which matters for the sensitivity.

\section{Concluding Remarks}

Our knowledge of labor supply behavior is subject to a good deal of uncertainty. Nonetheless, it seems to be the consensus that most of the variation in labor supply stems from decisions about entry and exit, and to a much lesser extent from changes in the hours of work for those who are working. This view carries important implications for tax policy. On a theoretical level, the welfare cost of raising revenue becomes a function of average tax levels and out-of-work income, rather than just marginal taxes as in the existing measures. Moreover, our calculations for 
Table III. The marginal cost of public funds in OECD countries for different labor supply elasticities

\begin{tabular}{|c|c|c|c|c|c|c|c|c|}
\hline \multirow[b]{3}{*}{ Country } & \multicolumn{4}{|c|}{ Variation in the participation elasticity } & \multicolumn{4}{|c|}{ Variation in the hours-of-work elasticity } \\
\hline & \multicolumn{2}{|c|}{$\delta=0.3$ and $\eta=0$} & \multicolumn{2}{|c|}{$\delta=0.4$ and $\eta=0$} & \multicolumn{2}{|c|}{$\delta=0.2$ and $\eta=0.1$} & \multicolumn{2}{|c|}{$\delta=0.2$ and $\eta=-0.1$} \\
\hline & Excl. benefits & Incl. benefits & Excl. benefits & Incl. benefits & Excl. benefits & Incl. benefits & Excl. benefits & Incl. benefits \\
\hline Australia & 1.25 & 1.49 & 1.36 & 1.79 & 1.30 & 1.47 & 1.03 & 1.14 \\
\hline Austria & 1.75 & 3.29 & 2.33 & 13.88 & 1.82 & 2.70 & 1.14 & 1.42 \\
\hline Belgium & 2.99 & 10.59 & 8.90 & -4.82 & 3.31 & 7.01 & 1.23 & 1.54 \\
\hline Canada & 1.32 & 1.52 & 1.48 & 1.85 & 1.38 & 1.52 & 1.05 & 1.13 \\
\hline Denmark & 1.68 & 2.56 & 2.16 & 5.32 & 1.72 & 2.24 & 1.14 & 1.35 \\
\hline Finland & 1.94 & 3.91 & 2.84 & 128.95 & 2.06 & 3.19 & 1.15 & 1.44 \\
\hline France & 1.69 & 2.20 & 2.19 & 3.68 & 1.72 & 2.04 & 1.14 & 1.28 \\
\hline Germany & 2.15 & 4.80 & 3.49 & -18.01 & 2.31 & 3.81 & 1.17 & 1.47 \\
\hline Greece & 1.38 & 1.45 & 1.58 & 1.70 & 1.41 & 1.46 & 1.08 & 1.11 \\
\hline Iceland & 1.27 & 1.68 & 1.39 & 2.17 & 1.31 & 1.57 & 1.05 & 1.21 \\
\hline Ireland & 1.58 & 2.15 & 1.96 & 3.47 & 1.75 & 2.16 & 1.07 & 1.21 \\
\hline Italy & 1.70 & 1.70 & 2.23 & 2.23 & 1.76 & 1.76 & 1.14 & 1.14 \\
\hline Japan & 1.15 & 1.32 & 1.21 & 1.48 & 1.16 & 1.27 & 1.04 & 1.13 \\
\hline Luxembourg & 1.45 & 2.13 & 1.71 & 3.40 & 1.51 & 1.94 & 1.08 & 1.28 \\
\hline Netherlands & 1.76 & 3.46 & 2.36 & 19.24 & 1.87 & 2.87 & 1.12 & 1.42 \\
\hline New Zealand & 1.16 & 1.34 & 1.22 & 1.51 & 1.16 & 1.28 & 1.04 & 1.14 \\
\hline Norway & 1.45 & 1.89 & 1.71 & 2.69 & 1.47 & 1.75 & 1.10 & 1.25 \\
\hline Portugal & 1.34 & 1.84 & 1.51 & 2.55 & 1.36 & 1.67 & 1.08 & 1.26 \\
\hline Spain & 1.38 & 1.61 & 1.58 & 2.03 & 1.41 & 1.56 & 1.08 & 1.17 \\
\hline Sweden & 1.70 & 2.75 & 2.22 & 6.58 & 1.71 & 2.30 & 1.15 & 1.39 \\
\hline Switzerland & 1.22 & 1.64 & 1.32 & 2.08 & 1.25 & 1.50 & 1.05 & 1.23 \\
\hline United Kingdom & 1.30 & 1.68 & 1.44 & 2.17 & 1.32 & 1.57 & 1.06 & 1.21 \\
\hline United States & 1.21 & 1.24 & 1.29 & 1.35 & 1.21 & 1.24 & 1.05 & 1.07 \\
\hline
\end{tabular}

Source: $\operatorname{OECD}(2000,2001 \mathrm{a}, \mathrm{b})$ and authors' own calculations.

Note: MCF is calculated from equation (16) using the tax and beneft rates reported in Table I. We consider a proportional tax reform $(\Phi=1)$. Under this reform, the decomposition of the uncompensated hours-of-work elasticity $(\eta)$ into a compensated elasticity $\left(\eta^{c}\right)$ and an income effect $(\theta)$ is irrelevant for the MCF. 
OECD countries indicate that the costs of financing public goods become considerably higher once participation responses are accounted for.

Although our paper is concerned primarily with the level of taxation, the analysis has interesting implications for the composition of taxation. The empirical labor market literature demonstrates clearly that participation elasticities are substantially larger for low-wage earners than for high-wage earners. This implies, ceteris paribus, that the raising of labor taxes on low-wage earners involves a relatively high MCF. This suggests an efficiency-based argument for low tax burdens at the bottom of the wage-distribution, for example through the use of an Earned Income Tax Credit (EITC). Such a conclusion clashes with the existing MCF literature where tax increases in lower brackets carry a large element of lump sum taxation implying a low value for MCF, a point emphasized by Dahlby (1998). Our point is instead in line with that of Saez (2000) who extends the theory of optimal income taxation to incorporate both intensive and extensive labor supply responses. His analysis demonstrates that, when labor supply responses are concentrated on the extensive margin, the optimum involves an EITC with negative tax rates for low-wage earners. All in all, our analysis and that of Saez indicate that the distinction between the two margins of labor supply response is important for both the level and the composition of taxation. 


\section{Appendix}

Eq. (14) is obtained by deriving the two derivatives $d \tilde{\omega} / d z$ and $d l_{p} / d z$ and inserting them into eq. (13). We start by deriving $d \tilde{\omega} / d z$. From the participation condition (4), we have

$$
\frac{d \tilde{\omega}}{d z}=v_{1} \frac{d c_{p}}{d z}-v_{2} \frac{d l_{p}}{d z}
$$

where we have used that $d c_{n} / d z=-\partial T(0, z) / \partial z=0$. Using the budget constraint (2) to derive $d c_{p} / d z$, the above relationship becomes

$$
\frac{d \tilde{\omega}}{d z}=\left[(1-m(z)) w v_{1}-v_{2}\right] \frac{d l_{p}}{d z}-v_{1} \frac{\partial a}{\partial z} w l_{p}
$$

where we have used that $\partial a / \partial z \equiv \frac{\partial T / \partial z}{w l_{p}}$. Finally, due to the first order condition with respect to hours, eq. (3), the first term vanishes, and we arrive at

$$
\frac{d \tilde{\omega}}{d z}=-v_{1} \frac{\partial a}{\partial z} w l_{p}
$$

We next derive $d l_{p} / d z$. Note first that the budget constraint may be rewritten to

$$
c_{p}=(1-m(z)) w l_{p}+I
$$

where $I \equiv m(z) w l_{p}-T\left(w l_{p}, z\right)+y$ is the so-called virtual income. This expression and eq. (3) imply that the optimal number of working hours may be written as a function of the marginal net-of-tax wage and the virtual income, i.e.

$$
l_{p}=l_{p}((1-m(z)) w, I) .
$$

The impact of a marginal change in $z$ becomes

$$
\frac{d l_{p}}{d z}=-\frac{\partial l_{p}}{\partial[(1-m) w]} w \frac{\partial m}{\partial z}+\frac{\partial l_{p}}{\partial I} \frac{d I}{d z}
$$


From the definition of the virtual income we obtain

$$
\frac{d I}{d z}=\frac{\partial m}{\partial z} w l_{p}+m w \frac{d l_{p}}{d z}-m w \frac{d l_{p}}{d z}-\frac{\partial a}{\partial z} w l_{p}=\left(\frac{\partial m}{\partial z}-\frac{\partial a}{\partial z}\right) w l_{p}
$$

implying that

$$
\frac{d l_{p}}{d z}=-\frac{\partial l_{p}}{\partial[(1-m) w]} w \frac{\partial m}{\partial z}+\frac{\partial l_{p}}{\partial I}\left(\frac{\partial m}{\partial z}-\frac{\partial a}{\partial z}\right) w l_{p}
$$

Using the definition of the uncompensated hours-of-work elasticity, $\eta \equiv \frac{\partial l_{p}}{\partial[(1-m) w]} \frac{(1-m) w}{l_{p}}$, and the relationship $\partial l_{p} / \partial y=\partial l_{p} / \partial I$, the above expression may be written as

$$
\frac{d l_{p}}{d z}=-\frac{l_{p}}{1-m}\left[\frac{\partial m}{\partial z} \eta^{c}-\frac{\partial a}{\partial z} \theta\right]
$$

where we have used the Slutsky-equation (7) and the definition of $\theta$.

Finally, by inserting (18) and (19) in eq. (13) and using (8), we obtain eq. (14). QED. 


\section{References}

Ashenfelter, O. (1978). "The Labor Supply Response of Wage Earners," in J. Palmer and J. Pechman (eds.), Welfare in Rural Areas. The Brookings Institution: Washington D. C.

Atkinson, A. B. and N. H. Stern (1974). "Pigou, Taxation and Public Goods." Review of Economic Studies 41, 119-128.

Ballard, C. L. and D. Fullerton (1992). "Distortionary Taxes and the Provision of Public Goods." Journal of Economic Perspectives 6, 117-131.

Blundell, R. W. and T. MaCurdy (1999). "Labor Supply: A Review of Alternative Approaches," in O. Ashenfelter and D. Card (eds.), Handbook of Labor Economics vol. 3A. Elsevier Science B.V.: Amsterdam.

Browning, E. K. (1976). "The Marginal Cost of Public Funds." Journal of Political Economy $84,283-298$.

Browning, E. K. (1987). "On the Marginal Welfare Cost of Taxation." American Economic Review 77, 11-23.

Browning, E. K. and W. R. Johnson (1984). "The Trade-Off between Equality and Efficiency." Journal of Political Economy 92, 175-203.

Browning, M., L. P. Hansen, and J. J. Heckman (1999). "Micro Data and General Equilibrium Models," in J. B. Taylor and M. Woodford (eds.), Handbook of Macroeconomics vol. 1A. Elsevier Science B.V.: Amsterdam.

Dahlby, B. (1998). "Progressive Taxation and the Social Marginal Cost of Public Funds." Journal of Public Economics 67, 105-122.

Eissa, N. (1995). "Taxation and Labor Supply of Married Women: The Tax Reform Act of 1986 as a Natural Experiment." NBER Working Paper No. 5023. 
Eissa, N. and J. Liebman (1996). "Labor Supply Response to the Earned Income Tax Credit." Quarterly Journal of Economics 61, 605-37.

Fullerton, D. (1991). "Reconciling Recent Estimates of the Marginal Welfare Cost of Taxation." American Economic Review 81, 302-308.

Heckman, J. J. (1993). "What Has Been Learned About Labor Supply in the Past Twenty Years?" American Economic Review Papers and Proceedings 83, 116-121.

Krueger, A. B. and B. D. Meyer (2002). "Labor Supply Effects of Social Insurance." NBER Working Paper No. 9014, forthcoming in A. J. Auerbach and M. Feldstein (eds.), Handbook of Public Economics.

Mayshar, J. (1991). "On Measuring the Marginal Cost of Funds Analytically." American Economic Review 81, 1329-1335.

Mendoza, E. G., A. Razin, and L. L. Tesar (1994). "Effective Tax Rates in Macroeconomics. Cross-Country Estimates of Tax Rates on Factor Incomes and Consumption." Journal of Monetary Economics 34, 297-323.

Mendoza, E. G., G. M. Milesi-Ferretti, and P. Asea (1997). "On the Ineffectiveness of Tax Policy in Altering Long-Run Growth: Harberger's Superneutrality Conjecture." Journal of Public Economics 66, 99-126.

Meyer, B. and D. Rosenbaum (2001). "Welfare, the Earned Income Tax Credit, and the Labor Supply of Single Mothers.” Quarterly Journal of Economics 66, 1063-1114.

Mroz, T. A. (1987). "The Sensitivity of an Empirical Model of Married Women's Hours of Work to Economic and Statistical Assumptions." Econometrica 55, 765-799.

OECD (2000). Taxing Wages: Income Tax, Social Security Contributions and Cash Family Benefits. OECD: Paris. 
OECD (2001a). Tax Ratios: A Critical Survey. OECD Tax Policy Studies No. 5. OECD: Paris.

OECD (2001b). Benefit Systems and Work Incentives. OECD: Paris.

Robins, P. K. (1985). "A Comparison of the Labor Supply Findings from the Four Negative Income Tax Experiments." Journal of Human Resources 20, 567-82.

Saez. E. (2000). "Optimal Income Transfer Programs: Intensive Versus Extensive Labor Supply Responses." NBER Working Paper No. 7708, forthcoming in Quarterly Journal of Economics.

Snow, A. and R. S. Warren Jr. (1996). "The Marginal Welfare Cost of Public Funds: Theory and Estimates." Journal of Public Economics 61, 289-305.

Stiglitz, J. E. and P. Dasgupta (1971). "Differential Taxation, Public Goods and Economic Efficiency." Review of Economic Studies 38, 151-174.

Stuart, C. (1984). "Welfare Costs per Dollar of Additional Tax Revenue in United States." American Economic Review 74, 352-362.

Triest, R. K. (1990). "The Effect of Income Taxation on Labor Supply in the United States." Journal of Human Resources 25, 491-516.

Usher, D. (1984). "An Instructive Derivation of the Expression for the Marginal Cost of Public Funds." Public Finance 39, 406-411.

Van Soest, A. (1995). "Discrete Choice Models of Family Labor Supply." Journal of Human Resources 30, 63-88.

Van Soest, A., M. Das, and X. Gong (2002). "A Structural Labor Supply Model with Flexible Preferences." Journal of Econometrics 107, 345-374. 
Wildasin, D. E. (1984). "On Public Good Provision With Distortionary Taxation." Economic Inquiry 22, 227-243. 


\title{
CESifo Working Paper Series
}

\author{
(for full list see www.cesifo.de)
}

869 M. Hashem Pesaran, Estimation and Inference in Large Heterogenous Panels with Cross Section Dependence, February 2003

870 Luis H. R. Alvarez and Erkki Koskela, On the Tree-Cutting Problem under Interest Rate and Forest Value Uncertainty, February 2003

871 Norbert Berthold and Rainer Fehn, Unemployment in Germany: Reasons and Remedies, February 2003

872 Clemens Fuest, Bernd Huber, and Philipp Tilleßen, Tax Policy and Entrepreneurship in the Presence of Asymmetric Information in Capital Markets, February 2003

873 Eytan Sheshinski, Optimum and Risk-Class Pricing of Annuities, February 2003

874 Willi Leibfritz, Paul O'Brien and Jean-Christophe Dumont, Effects of Immigration on Labour Markets and Government Budgets - An Overview, February 2003

875 M. Hashem Pesaran and Allan Timmermann, How Costly is it to Ignore Breaks when Forecasting the Direction of a Time Series?, February 2003

876 Thorvaldur Gylfason and Gylfi Zoega, Education, Social Equality and Economic Growth: A View of the Landscape, February 2003

877 Robin Boadway and Jean-François Tremblay, Public Economics and Startup Entrepreneurs, February 2003

878 Erkki Koskela and Roope Uusitalo, The Un-Intended Convergence: How the Finnish Unemployment Reached the European Level, February 2003

879 Robert Fenge and Volker Meier, Pensions and Fertility Incentives, February 2003

880 Eytan Sheshinski, Note on Income Taxation and Occupational Choice, February 2003

881 A B Atkinson, Income Inequality in OECD Countries: Data and Explanations, February 2003

882 Thomas Gehrig and Rune Stenbacka, Venture Cycles: Theory and Evidence, February 2003

883 Ralf Becker and Thomas Hellmann, The Genesis of Venture Capital - Lessons from the German Experience, March 2003

884 Eytan Sheshinski, Note on the Optimum Pricing of Annuities, March 2003 
885 Paul De Grauwe and Magdalena Polan, Globalisation and Social Spending, March 2003

886 F. van der Ploeg, Do Social Policies Harm Employment and Growth?, March 2003

887 Mirjam van Praag, Initial Capital Constraints Hinder Entrepreneurial Venture Performance: An empirical analysis, March 2003

888 Bernard Steunenberg, Coordinating Sectoral Policymaking: Searching for Countervailing Mechanisms in the EU Legislative Process, March 2003

889 Eytan Sheshinski, Optimum Delayed Retirement Credit, March 2003

890 Frederick van der Ploeg, Rolling Back the Public Sector - Differential effects on employment, investment and growth, March 2003

891 Paul De Grauwe and Marc-Alexandre Sénégas, Monetary Policy in EMU when the Transmission is Asymmetric and Uncertain, March 2003

892 Steffen Huck and Kai A. Konrad, Strategic Trade Policy and the Home Bias in Firm Ownership Structure, March 2003

893 Harry Flam, Turkey and the EU: Politics and Economics of Accession, March 2003

894 Mathias Hoffmann and Ronald MacDonald, A Re-examination of the Link between Real Exchange Rates and Real Interest Rate Differentials, March 2003

895 Badi H. Baltagi, Espen Bratberg, and Tor Helge Holmås, A Panel Data Study of Physicians' Labor Supply: The Case of Norway, March 2003

896 Dennis C. Mueller, Rights and Citizenship in the European Union, March 2003

897 Jeremy Edwards, Gains from Trade in Tax Revenue and the Efficiency Case for Trade Taxes, March 2003

898 Rainer Fehn and Thomas Fuchs, Capital Market Institutions and Venture Capital: Do They Affect Unemployment and Labour Demand?, March 2003

899 Ronald MacDonald and Cezary Wójcik, Catching Up: The Role of Demand, Supply and Regulated Price Effects on the Real Exchange Rates of Four Accession Countries, March 2003

900 R. Selten, M. Schreckenberg, T. Pitz, T. Chmura, and S. Kube, Experiments and Simulations on Day-to-Day Route Choice-Behaviour, April 2003

901 Stergios Skaperdas, Restraining the Genuine Homo Economicus: Why the Economy Cannot be Divorced from its Governance, April 2003

902 Yin-Wong Cheung, Menzie D. Chinn, and Antonio Garcia Pascual, What Do We Know about Recent Exchange Rate Models? In-Sample Fit and Out-of-Sample Performance Evaluated, April 2003 
903 Mika Widgrén, Enlargements and the Principles of Designing EU - Decision-Making Procedures, April 2003

904 Phornchanok Cumperayot, Dusting off the Perception of Risk and Returns in FOREX Markets, April 2003

905 Kai A Konrad, Inverse Campaigning, April 2003

906 Lars P. Feld and Stefan Voigt, Economic Growth and Judicial Independence: Cross Country Evidence Using a New Set of Indicators, April 2003

907 Giuseppe Bertola and Pietro Garibaldi, The Structure and History of Italian Unemployment, April 2003

908 Robert A.J. Dur and Otto H. Swank, Producing and Manipulating Information, April 2003

909 Christian Gollier, Collective Risk-Taking Decisions with Heterogeneous Beliefs, April 2003

910 Alexander F Wagner, Mathias Dufour, and Friedrich Schneider, Satisfaction not Guaranteed - Institutions and Satisfaction with Democracy in Western Europe, April 2003

911 Ngo Van Long, Raymond Riezman, and Antoine Soubeyran, Trade, Wage Gaps, and Specific Human Capital Accumulation, April 2003

912 Andrea Goldstein, Privatization in Italy 1993-2002: Goals, Institutions, Outcomes, and Outstanding Issues, April 2003

913 Rajshri Jayaraman and Mandar Oak, The Signaling Role of Municipal Currencies in Local Development, April 2003

914 Volker Grossmann, Managerial Job Assignment and Imperfect Competition in Asymmetric Equilibrium, April 2003

915 Christian Gollier and Richard Zeckhauser, Collective Investment Decision Making with Heterogeneous Time Preferences, April 2003

916 Thomas Moutos and William Scarth, Some Macroeconomic Consequences of Basic Income and Employment Subsidies, April 2003

917 Jan C. van Ours, Has the Dutch Miracle Come to an End?, April 2003

918 Bertil Holmlund, The Rise and Fall of Swedish Unemployment, April 2003

919 Bernd Huber and Marco Runkel, Optimal Design of Intergovernmental Grants under Asymmetric Information, April 2003

920 Klaus Wälde, Endogenous Business Cycles and Growth, April 2003 
921 Ramon Castillo and Stergios Skaperdas, All in the Family or Public? Law and Appropriative Costs as Determinants of Ownership Structure, April 2003

922 Peter Fredriksson and Bertil Holmlund, Improving Incentives in Unemployment Insurance: A Review of Recent Research, April 2003

923 Bernard M.S. van Praag and Adam S. Booij, Risk Aversion and the Subjective Time Discount Rate: A Joint Approach, April 2003

924 Yin-Wong Cheung, Dissecting the PPP Puzzle: The Unconventional Roles of Nominal Exchange Rate and Price Adjustment, April 2003

925 Ugo Trivellato and Anna Giraldo, Assessing the 'Choosiness' of Job Seekers. An Exploratory Approach and Evidence for Italy, April 2003

926 Rudi Dornbusch and Stanley Fischer, International Financial Crises, April 2003

927 David-Jan Jansen and Jakob de Haan, Statements of ECB Officials and their Effect on the Level and Volatility of the Euro-Dollar Exchange Rate, April 2003

928 Mario Jametti and Thomas von Ungern-Sternberg, Assessing the Efficiency of an Insurance Provider - A Measurement Error Approach, April 2003

929 Paolo M. Panteghini and Guttorm Schjelderup, Competing for Foreign Direct Investments: A Real Options Approach, April 2003

930 Ansgar Belke, Rainer Fehn, and Neil Foster, Does Venture Capital Investment Spur Employment Growth?, April 2003

931 Assar Lindbeck, Sten Nyberg, and Jörgen W. Weibull, Social Norms and Welfare State Dynamics, April 2003

932 Myrna Wooders and Ben Zissimos, Hotelling Tax Competition, April 2003

933 Torben M. Andersen, From Excess to Shortage - Recent Developments in the Danish Labour Market, April 2003

934 Paolo M. Panteghini and Carlo Scarpa, Irreversible Investments and Regulatory Risk, April 2003

935 Henrik Jacobsen Kleven and Claus Thustrup Kreiner, The Marginal Cost of Public Funds in OECD Countries. Hours of Work Versus Labor Force Participation, April 2003 